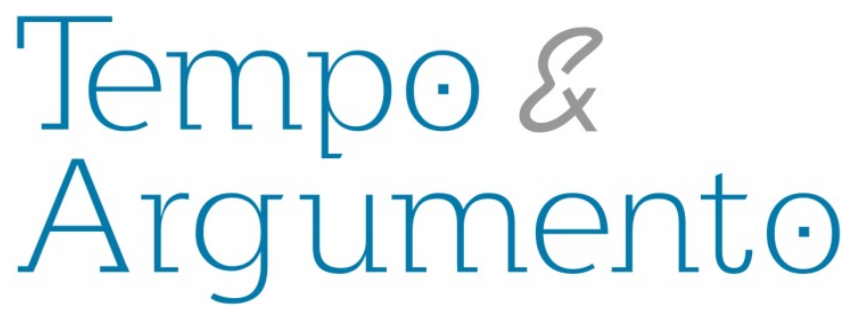

\title{
Apropriações de alunos do ensino médio quanto à história da cidade de Londrina-PR
}

\begin{abstract}
Resumo
Pretende-se divulgar resultados da pesquisa sobre como jovens estudantes do Ensino Médio das escolas públicas de Londrina - PR se apropriam da história/memória da cidade. Retomam-se os três estudos realizados segundo a "teoria fundamentada" (Grounded Theory): estudo exploratório (com Grupo Focal e brainstorming), estudo piloto (história hipotética) e estudo principal (netnografia). Este último, destacando duas questões que implicavam em análise de fontes históricas pelos estudantes. Utilizam-se como referenciais dois campos investigativos diferentes, mas interdependentes em alguns pontos: Didática da História e Educação Histórica. As ideias históricas dos alunos remetem à permanência de uma História Oficial/Tradicional sobre a cidade, mas nos mostra a potencialidade para a explicação histórica quando se tem possibilidade de debate, imaginação histórica capaz de construir empatia e interpretação comparativa de fontes históricas.
\end{abstract}

Palavras-chave: História; Ensino Médio; Estudo e Ensino; Londrina (PR); Cidades e Vilas.

\author{
Márcia Elisa Teté Ramos \\ Doutora em Educação na Universidade Federal do \\ Paraná. Professora do Programa de Pós- \\ Graduação em História Social da Unviersidade \\ Estadual de Londrina e professora do mestrado \\ profissional (profhistoria) da Universidade \\ Estadual de Maringa. \\ Brasil \\ mtete@uel.br
}

\section{Para citar este artigo:}

RAMOS, Márcia Elisa Teté. Apropriações de alunos do ensino médio quanto à história da cidade de Londrina-PR. Revista Tempo e Argumento, Florianópolis, v. 8, n. 19, p. 60 - 95. set./dez. 2016.

DOI: $10.5965 / 2175180308192016060$

http://dx.doi.org/10.5965/2175180308192016060 


\title{
Appropriations of high schools on the history of the city of Londrina-PR
}

\begin{abstract}
It is intended to disseminate research results on how high school young students of a public school Londrina appropriating history / memory of the city. Containing the three studies carried out according to the "Grounded Theory": an exploratory study (with Focus Groups and brainstorming) pilot study (hypothetical story) and the main study (netnography). The latter, highlighting two issues that involved in the analysis of historical sources by students. It is used as a reference two different investigative fields, but interdependent in some points: Didactic of History and History Education. The historical ideas of the students refer to the permanence of an Official History/Traditional over the city, rather conveyed in Public History, but it shows the potential for historical explanation when it has a chance to debate historical imagination can build empathy and comparative interpretation of historical sources.
\end{abstract}

Keywords: History; High School; Study and Teaching; Londrina (PR); Towns and Villages.

\section{Introdução}

Toda cidade tem marcas que a identificam, que a diferenciam das outras. Seus costumes, culturas, projetos, interesses, imagens, contradições, tensões, linguagens e carências. Toda cidade faz circular, por vários dispositivos, práticas e representações que atualizam suas histórias, suas memórias. Uma cidade tem muitas formas de ser representada, que se renovam ao longo do tempo (PESAVENTO, 2007, p. 11), e alguns elementos podem permanecer, como por exemplo, o que se conta sobre suas origens, acontecimento fundador, lideranças, dados, nomes e fatos (PESAVENTO, 2007, p. 12). Além disso, se atualizam os esquecimentos, pois as cidades também marginalizam, excluem, escondem histórias e memórias. 
Os sujeitos em sua relação com a cidade, reinterpretam, assimilam, interagem, compartilham, ou mesmo transgridem as histórias que ela narra através de sua arquitetura, monumentos, vestígios, museus, acervos, homenagens, discursos, etc. Por isso, me interessei por pesquisar no pós-doutoramento, como jovens estudantes do Ensino Médio de escolas públicas de Londrina', Estado do Paraná, se apropriavam das histórias e memórias circulantes na e sobre a cidade.

A pesquisa, seguindo a metodologia da Grounded Theory dividiu-se em três fases: 1) estudo exploratório, quando foi utilizada a técnica de Grupos Focais e de brainstorming (chuva de ideias), realizado no segundo semestre de 2014, sendo esta fase com 32 alunos dos $3^{\circ}$ s anos na faixa etária de 17 a 19 anos; 2) estudo piloto, com a técnica de "história hipotética", realizado no primeiro semestre de 2015, esta fase com 64 alunos de $2^{\circ} \mathrm{s}$ e $3^{\circ} \mathrm{s}$ anos, com a faixa etária de 15 a 19 anos e 3) estudo principal, que utilizou a netnografia, realizado no segundo semestre de 2015 , com 116 alunos dos $1^{\circ} \mathrm{S}, 2^{\circ} \mathrm{S}$ e $3^{\circ} \mathrm{S}$ anos, na faixa etária de 14 a 20 anos, centrando a discussão em torno de uma reportagem da revista Veja e duas reportagens do Jornal de Londrina, sobre a cidade de Londrina.

Segui dois campos investigativos diferentes, mas que não se excluem: a Didática da História e a Educação Histórica. Para Ronaldo Cardoso Alves, a Didática da História (de vertente alemã) "parte da racionalidade histórica, estruturada principalmente no espaço escolar, que relaciona a História às necessidades da vida cotidiana com a finalidade de construir consciência histórica", enquanto que a Educação História (principalmente a vertente anglo-saxã) "toma a vivência escolar como ponto de partida para a construção do conhecimento histórico, mediada por uma reflexão epistemológica construtora de metodologias que dotem alunos e professores de habilidades e competências históricas que os façam ler e agir no mundo que os cerca" (ALVES, 2013, p. 60). Devido ao propósito deste texto, apresento no momento apenas as semelhanças destes campos: o fato de ter como pressuposto investigativo as problemáticas referentes ao modo de como se elabora o conhecimento histórico de forma escolar e/ou extraescolar considerando a relação entre História e vida prática.

\footnotetext{
${ }^{1}$ Londrina é um município brasileiro localizado no Estado do Paraná, na Região Sul do Brasil, distando 381 $\mathrm{km}$ da capital paranaense, Curitiba. Tem uma população de 548249 habitantes segundo dados do IBGE de 2015, sendo a segunda cidade mais populosa do Estado e a quarta da Região Sul, depois da capital estadual, Curitiba, de Porto Alegre e de Joinville.
} 
Pretendo divulgar os resultados desta pesquisa, mostrando o referencial teórico e a metodologia utilizada nos três estudos realizados. Reúno os resultados em discursossínteses, ou seja, "resumindo" o que determinado grupo de estudantes de Ensino Médio pensa sobre a história narrada na e sobre a cidade. Este tipo de estudo nos remete à reflexão sobre História Pública, ou seja, sobre: "usos da memória; usos do passado; demanda social; percepção pública da história (...)” (SANTHIAGO, 2016, p. 26). Portanto, os estudantes revelaram a internalização de formas não institucionais de história. Embora a escola seja (ou devesse ser) o espaço público por excelência da circulação, da construção e da ressignificação do conhecimento histórico, outras formas de elaborações históricas parecem fazer mais sentido aos estudantes.

\section{Referenciais: Didática da História, Educação Histórica e a cidade como texto pedagógico}

Para Bergmann, a preocupação da Didática da História está voltada para a investigação sobre: o que é apreendido no ensino de história (ação empírica, cujo objetivo é abranger a elaboração da História e sua compreensão, tanto no ambiente acadêmico, como na escola ou em outras esferas sociais), o que pode ser apreendido (reflexão sobre os interesses, problemáticas, pressupostos, teorias, métodos, formas de exposição), o que deveria ser apreendido (tarefa normativa, que enfoca as formas de mediação intencional e da representação ou exposição da história) (BERGMANN, 1980/1990, p. 29-31). Para este autor, a Didática da História através destes itens tem uma tarefa política, pois busca ter parâmetros para refletir sobre a intervenção na realidade por intermédio da explicação própria da racionalidade histórica.

Enquanto que a pergunta-base nas pesquisas mais tradicionais sobre ensino de história estavam centradas em como motivar alunos para a aprendizagem de história, ou em como utilizar estratégias/recursos didáticos para atingir bons resultados, ou ainda, em quais as atividades didático-pedagógicas de um ensino de história de sucesso, a problemática posta pela vertente da Educação Histórica corre no sentido de responder sobre como os alunos compreendem a história (BARCA, 2009, p. 12), e mais: sobre para 
que serve aprender história. Embutidas nesta questão estão outras: para saber como os alunos aprendem história, preciso partir dos saberes que eles já têm sobre história; preciso saber também sobre os saberes que os professores de história apresentam (saberes históricos, pedagógicos e experienciais) e é necessário saber qual o significado que os alunos e professores de história dão para o conhecimento histórico (O que é? Para que serve? É importante ou não?). Segundo Isabel Barca, esta linha de investigação busca uma "observação sistemática do real”, não se centrando nos "formalismos e recursos da aula", embora estes sejam também importantes, mas nas "ideias históricas de quem aprende e ensina" (BARCA, 2008, p. 24). Conhecer as ideias históricas dos agentes escolares implica em um "enquadramento teórico que respeite a natureza do saber histórico e que deve refletir-se, do mesmo modo, na aula de História". (BARCA, 2005, p. 15). Também na Educação Histórica, a finalidade última é um ensino de história de qualidade, que significa utilizar-se da racionalidade histórica para entender o mundo.

Tanto na Didática da História como na Educação Histórica, as elaborações históricas dos sujeitos precisam ser conhecidas para que sejam pontos de partida para a construção da racionalidade histórica. Ao entender que as protonarrativas dos alunos permitem a compreensão sobre como explicam o passado, termino por adentrar no conceito de representações, que resumo aqui em acordo com Nicole Tutiaux-Guillon: “A representação social é um produto cognitivo que mistura experiência, julgamento, conhecimento, afeto e resulta de uma interação social e socialização" (TUTIAUX-NILLON, 2011, p. 23). São noções, saberes, ideias, insights, construídos de forma não científica (embora também fragmentos da ciência sejam incorporados), e permeiam a comunicação, a compreensão. Mais ainda: interferem na decisão e ação (TUTIAUXNILLON, 2011, p. 24).

A cidade narra uma história, elegendo imagens, personagens, perspectivas para serem lembradas. Segundo Barthes, existiria uma "semiótica urbana", com "suas oposições de lugares, com sua sintaxe e os seus paradigmas" (BARTHES, 1985, p. 181). A cidade teria uma "escrita”, seria um “texto", que como tal, poderia ser "lido" e/ou “interpretado", dependendo do "leitor": “A cidade é um discurso, e esse discurso é verdadeiramente uma linguagem: a cidade fala a seus habitantes, nós falamos nossa 
Se a cidade pode ser vista como um "texto", "o seu leitor privilegiado seria o habitante (ou o visitante) que se desloca através da cidade” (BARROS, 2012, p. 40): “(...) o complexo discurso urbano aloja dentro de si diversos discursos de todas as ordens. A cidade também fala aos seus habitantes e aos seus visitantes através dos nomes próprios que ela abriga: dos nomes de ruas, de edifícios, de monumentos". (BARROS, 2012, p. 45).

A cidade entendida como texto nos remete também a Roger Chartier. Para ele, um texto, um discurso não possui sentido intrínseco, absoluto e único, e depende sempre das operações de sentido, dos usos produzidos pelos “leitores". A leitura - a apropriação seria uma prática criadora, inventiva e produtora, que dá aos textos significações plurais e móveis (CHARTIER, 1996, p. 78). A cidade seria um suporte para determinada narrativa histórica, ou seja, seria uma fonte histórica específica, e assim, sua "leitura" também seria específica: "não existe nenhum texto fora do suporte que o dá a ler, que não há compreensão de um escrito, qualquer que ele seja, que não dependa das formas através das quais ele chega a seu leitor" (CHARTIER, 1990, p. 127). Chartier entende que, para os leitores, o "texto" configura-se em possibilidade de produção de sentido, ainda que esta produção não seja aleatória. Porém, a produção (ou invenção) de sentido, a apropriação "está sempre inscrita dentro de coações, restrições e limitações compartilhadas", ao mesmo tempo em que "sempre desloca ou supera estas limitações" (CHARTIER, 2001, p. 33). Por isso, a cidade, ao mesmo tempo em que provoca um "sentido preferencial" quanto à sua história/memória, também fomenta apropriações diversas. Em outras palavras, não devemos extremar nem a imposição "História Oficial” pela cidade, nem a prática criadora da "leitura" de seus habitantes. Mas considerando tanto as possibilidades quanto as limitações da apropriação, vale questionar em que medida o sujeito teria total independência em relação às mensagens que a cidade passa quanto à sua história/memória.

Argumentam Sônia Regina Miranda e Joan Pagés Blanch que no âmbito mundial a cidade vem sendo tematizada no debate educacional, “como um lócus múltiplo, plural e permanente, passível de reinterpretação e ressignificação nos mais diferentes territórios 
e experiências sociais" (MIRANDA; BLANCH. 2013, p. 63). Por isso mesmo, seria interessante "a interpelação dos sentidos e consciência histórica que pode ser ativada a partir da experiência com a pluralidade urbana efetiva” (MIRANDA; BLANCH. 2013, p. 66). Se considerarmos que Goodson entende, no campo do currículo, "reconceptualização alargada dos estudos que o tomam como objecto de análise" (GOODSON, 2001, p. 52), como material que é elaborado e processado em uma diversidade de áreas e níveis, na prescrição, na prática, no discurso (GOODSON, 1995, p. 187), a cidade de Londrina seria um currículo, ou seja, um espaço em que se percebem ou se aprendem determinados saberes históricos sobre a cidade.

\section{Discurso-síntese: Londrina narra muito mais uma História Oficial do que uma história crítica}

Para a efetivação da proposta de levantamento das protonarrativas dos alunos, há que se demarcar que a pesquisa que se apresenta é próxima à pesquisa etnográfica. Por que próxima? A pesquisa etnográfica exige uma imersão do pesquisador por longo prazo no campo de pesquisa, o que é problemático e invasivo quando se trata da escola com suas rotinas e burocracias. Por isso, apenas o Estudo Piloto ( $2^{\text {a }}$ fase) foi realizado em sala de aula, mas não houve observação do campo. Portanto, o presente estudo se refere a uma unidade social, por abarcar o grupo dos sujeitos estudantes, mas não os vê, necessariamente, em seu contexto espacial real. Englobei diversos tipos de metodologias, pautando-me no que se denomina "teoria fundamentada" (Grounded Theory), pois nela, é na trajetória de pesquisa que vai se pensando e selecionando metodologias, temas e grupo de sujeitos a serem investigados, que possam dar conta do objetivo da mesma. O fato de ter diferentes técnicas combinadas para colhimento dos dados e evidências permite uma triangulação de resultados com um grau mais “confiável”, "plausível” ou “consistente”. É também no processo da pesquisa que vai se criando categorias de análise partindo das respostas, depoimentos, conversas dos alunos: “A Grounded Theory, GT, visa desenvolver uma teoria sobre a realidade que se está investigando - nesta situação de Estudo de Caso -, a partir de dados coletados pelo pesquisador, sem considerar hipóteses preconcebidas" (MARTINS; THEÓPHILO, 2009, p. 
qual o próximo dado a coletar e onde encontrá-lo. Na medida em que o pesquisador compara vários casos, a teoria vai emergindo" (MARTINS; THEÓPHILO, 2009, p. 77). Uma teoria considerada "substantiva", ou seja, aquela que representa o mais próximo possível da realidade dos sujeitos da pesquisa, e, "saturada", quando nenhum dado adicional contribuirá mais para a compreensão do fenômeno (MARTINS; THEÓPHILO, 2009, p. 7677).

Para dar corpo à "teoria fundamentada", os estudos foram os seguintes:

\begin{tabular}{|l|c|l|l|l|l|}
\hline \multicolumn{1}{|c|}{ Etapa } & $\begin{array}{l}\text { Quant. de } \\
\text { alunos }\end{array}$ & \multicolumn{1}{c|}{ Série } & \multicolumn{1}{c|}{ Período } & \multicolumn{1}{c|}{ Local } & \multicolumn{1}{c|}{ Técnica } \\
\hline $\begin{array}{l}\text { Estudo } \\
\text { exploratório }\end{array}$ & 32 alunos & $3^{\circ}$ ano & $\begin{array}{l}2^{\circ} \text { semestre } \\
2014\end{array}$ & $\begin{array}{l}\text { Museu } \\
\text { Histórico de } \\
\text { Londrina }\end{array}$ & $\begin{array}{l}\text { Grupos Focais e } \\
\text { Chuva de Ideias }\end{array}$ \\
\hline $\begin{array}{l}\text { Estudo } \\
\text { piloto }\end{array}$ & 64 alunos & $\begin{array}{l}2^{\circ} \mathrm{e} 3^{\circ} \\
\text { anos }\end{array}$ & $\begin{array}{l}1^{\circ} \text { semestre } \\
2015\end{array}$ & Sala de aula & História Hipotética \\
\hline $\begin{array}{l}\text { Estudo } \\
\text { principal }\end{array}$ & 116 alunos & $\begin{array}{l}1^{\circ}, 2^{\circ} \text { e } 3^{\circ} \\
\text { anos }\end{array}$ & $\begin{array}{l}2^{\circ} \text { semestre } \\
2015\end{array}$ & Virtual & Netnografia \\
\hline
\end{tabular}

Tabela 1: Informações sobre os três estudos realizados (2014-2015)

Disponho a pesquisa por intermédio de seus três estudos, destacando os discursos-sínteses dos sujeitos. No discurso-síntese se reúnem “conteúdos e argumentos que conformam opiniões semelhantes" (LEFEBRE; LEFEBRE, 2012, p. 17). Assim, apanho as respostas semelhantes como se fossem um depoimento único (LEFEBRE; LEFEBRE, 2012, p. 19). Esta metodologia denominada Discurso do Sujeito Coletivo (DSC) serve ao propósito de reunir depoimentos verbais e não verbais em discursos-sínteses, entendendo que em qualquer sociedade os sujeitos compartilham e também divergem em ideias, noções, opiniões e representações, e por isso mesmo, estas podem ser percebidas conforme "padrões", fazendo o pensamento coletivo "falar diretamente" (LEFEBRE; LEFEBRE, 2012, p. 24). O discurso-síntese seria mensagem nuclear de um conjunto de narrativas e não deixa de ser uma forma de categorização, uma forma de reconhecer, diferenciar e classificar aproximadamente as representações sociais. 


\subsection{Estudo Exploratório: “Um shopping também conta a história de Londrina?”}

No Estudo Exploratório, optei pela técnica de Grupo Focal por entender que tal metodologia fomenta o debate, a interação entre os envolvidos (pesquisadora, professor e alunos-respondentes), revelando convergências e conflitos de ideias e assim, possibilitando o levantamento de questões não-previstas para o estudo posterior. A pergunta que lancei aos alunos, Onde mais, além do Museu, se conta a história da cidade?, configura-se em uma estratégia para direcionar uma forma de conhecimento situacional, ou seja, ao aluno “... pede-se que pense em determinado recorte da realidade que se apresenta e que procure uma posição ou ponto de vista em relação a ela" (EDWARDS, 1997, p. 24). Este tipo de pergunta prioriza as vivências dos alunos, a significação de uma realidade, os usos e sistemas valorativos que possui, e não as definições abstratas.

Neste sentido, o espaço museal, lugar em que foi realizada a discussão do Grupo Focal, foi usado como dispositivo de evocação para iniciar a discussão. A exposição permanente do Museu Histórico de Londrina é propícia para se compreender como se constrói uma narrativa histórica e como se pode realizar uma crítica em relação a esta narrativa. Este museu narra a história de Londrina, cidade relativamente jovem - 81 anos, considerando desde o período anterior à colonização, quando os indígenas Kaingáng, Guarani e Xetá aqui habitavam, até a contemporaneidade, com as primeiras indústrias (em especial, do café) que se estabeleceram na região. Sua exposição permanente comporta cenários como, por exemplo: “venda”, “cozinha”, “indústria”, “imprensa” (jornal), "alfaiataria", etc. Tais cenários procuram reproduzir o ambiente do passado, procurando criar uma empatia no público, o que de fato acontece. Contudo, os artefatos indígenas ocupam um espaço mínimo, sendo que se encontram não propriamente na sala de exposição, mas em uma espécie de hall de entrada, como se se estivesse "fora" da história². A exposição culmina na indústria de café solúvel, destacando determinada marca. Desta forma, os estudantes já estavam em um lugar que se propõe mostrar a história de Londrina, que por sua vez é apresentada mediante possibilidades e limitações.

\footnotetext{
${ }^{2}$ Este modo de representar o indígena como sujeito anistórico foi reconhecido pelos últimos diretores do MHL.
} 
A técnica de Grupo Focal requer um moderador que guia cada grupo - de aproximadamente 10 a 15 pessoas - em uma discussão que pretende revelar experiências, sentimentos, atitudes, percepções, preferências. Os grupos são formados com participantes que têm características em comum e são incentivados pelo moderador a conversarem entre si, trocando experiências e interagindo com ideias, sentimentos, valores, dificuldades. O papel do moderador-entrevistador é de elaborar um roteiro de discussão, elucidar ao grupo o propósito da pesquisa, identificar como utilizará as informações, promover a participação de todos sem interferir, evitar a dispersão dos objetivos da discussão e a monopolização de alguns participantes sobre outros e registrar a discussão fenômeno (MARTINS; THEÓPHILO, 2009).

Como disse, estes alunos não se encontravam no espaço escolar, mas no Museu Histórico de Londrina, o que não exclui o fato de que estavam em uma situação escolar, na medida em que se apresentava uma atividade extraescolar, mas com finalidades didático-pedagógicas. Como qualquer situação escolar, a visita ao museu compreendeu uma série de "rotinas" em que os sujeitos escolares, professor e alunos - e no caso, também a pesquisadora -, dispõem intenções, objetivos e noções de forma interativa. Em situação escolar, os sujeitos "constroem coletivamente um conjunto de conhecimentos" partindo da mobilização de conhecimentos prévios (EDWARDS, 1997, p. 55), ou seja, nunca há um "ponto de partida absoluto" para a construção do conhecimento (EDWARDS, 1997, p. 52). Deste modo, a técnica de Grupos Focais acentuou as características próprias da situação escolar no espaço museal, pois promoveu um debate entre os sujeitos.

Destes alunos, 12 responderam conforme a noção de que "vestígios" do passado se encontram na paisagem da cidade em forma de prédios ou casas (citaram o Cine Teatro Ouro Verde ${ }^{3}$, a Casa do Pioneiro presente na UEL e a réplica da primeira igreja matriz católica também presente na UEL), e estes contariam a história de Londrina.

\footnotetext{
3 O teatro foi inaugurado em 24 de dezembro de 1952, enquanto a cidade vivia o auge da exploração cafeeira, daí o nome Ouro Verde. O projeto foi realizado por Villanova Artigas, contando inicialmente com 1500 lugares. Em 1978, o Cine Ouro Verde foi adquirido pela Universidade Estadual de Londrina e seu nome foi mudado para Cine Teatro Universitário Ouro Verde. Em 12 de fevereiro de 2012, um incêndio destruiu o edifício e hoje este se encontra em restauração.
} 
Outros alunos (5 dos 32) entenderam que a história da cidade pode ser encontrada em fontes de um acervo, o Centro de Pesquisa e Documentação Histórica de Londrina (UEL), além do próprio Museu. A história também seria contada, para 3 alunos, através de monumentos (citaram o Memorial dos Pioneiros ${ }^{4}$ ). Alguns alunos não souberam ou não quiseram responder (4 alunos). Interessante foram 8 respostas: a história da cidade seria contada pelo Boulevard Londrina Shopping.

Quanto à possibilidade da história ser contada em um shopping, apesar de oito alunos em um total de 32 a terem mencionado, é importante retomar. Alguns espaços da cidade são ícones da narrativa histórica "oficial”, como é o caso do shopping citado pelos alunos. Este recorre aos ícones ingleses - Big Ben, Rainha Elizabeth II, London Eye, Sherlock Holmes, bonecos-guardas da Rainha, placa dos caixas eletrônicos iguais às placas do metrô londrino, etc., para ambientar sua arquitetura e decoração, partindo da noção de "origem" inglesa da fundação da cidade. Existe neste shopping um conjunto de práticas de aproximação com o universo cultural inglês, como o jogo de críquete - que não perdurou, sendo substituído por uma pista de autorama - ou as imagens do livro Alice no País das Maravilhas, The Beatles ou da Rainha presentes nos sanitários. Não apenas neste shopping, mas na cidade, são muitos os ícones ingleses, entre eles: as cabines telefônicas seguem o modelo londrino e o portal da cidade conta com seis Big Bens e bonecos simulando a guarda da Rainha.

Apesar das várias etnias/nacionalidades que imigraram para a região, houve a supervalorização dos ingleses nas narrativas históricas tradicionais. Uma tabela de imigração de 1938 aponta a presença de 7 ingleses em Londrina, ao contrário do grupo de italianos, de japoneses e de espanhóis com 500-600 pessoas cada (YAMAKI, 2003 apud SILVA, 2011). Representações circulam na cidade instaurando-a como sendo de origem europeia, em especial, inglesa, porém, não existe uma "colônia", ou bairro ou região habitada por ingleses, pois estes não se estabeleceram na região, ficando na cidade por pouco tempo, na fase inglesa da colonização (de 1930 a 1951).

\footnotetext{
${ }^{4}$ Formado por 17 totens, localizados na Praça Primeiro de Maio (conhecida como Concha Acústica), onde se pode ver a inscrição dos nomes de 3.800 famílias que se cadastraram no MHL como sendo "pioneiras" (que chegaram a Londrina, de 21/08/1929 a 31/12/1939). Dois totens não possuem nomes, mas são destinados aos "indígenas" e aos "desbravadores".
} 
Apesar de a história ser posta de forma temática, espetacularizada e lúdica no shopping, a repetição de uma mensagem termina por ser internalizada. Assim, uma narrativa histórica constantemente reproduzida termina por "inventar uma tradição", quando um conjunto de práticas, de natureza ritual ou simbólica, "visam inculcar certos valores e normas de comportamento através da repetição" (HOBSBAWM, 1984, p. 9). Este shopping é um espaço que pode ser considerado como uma narrativa da história espetacularizada, ou seja, correspondendo à cultura midiática com a qual, principalmente os jovens, encontram afinidade. Segundo Beatriz Sarlo, o shopping apresenta um "modelo de cidade de serviços miniaturizada" e praticamente se autonomiza diante da cidade, criando um a atmosfera irreal de onde a história está ausente. Por vezes, "a história é usada para desempenhar um papel servil, convertendo-se em decoração banal” (SARLO, 2004, p. 18). A história no shopping seria um souvenir, mesmo porque se um espaço como este pretendesse apresentar uma história "séria", haveria um choque de finalidades, já que seu último significado seria mercantil, em que os objetos são efêmeros e descartáveis, portanto, anistóricos (SARLO, 2004, p. 21). Ainda argumenta a autora, que os jovens são os mais propensos a entender os significados que o shopping transmite. A suspensão do tempo, o labirinto do espaço, o discurso fast, "a velocidade de circulação, e, portanto, a obsolescência acelerada", então combinam com a juventude, sob o mesmo mito da novidade e da renovação que também a impulsiona (SARLO, 2004, p. 40-41).

As respostas dos alunos que sinalizaram o referido shopping como lugar em que se narra a história na cidade justificam-se por ser um espaço, - depois da internet, onde os jovens estudantes passam a maior parte de seu tempo de lazer. No caso, os 32 alunos teriam acesso à internet e a média diária de tempo em que ficam na internet é de quatro horas. Os alunos acessam principalmente as redes sociais, mas também Youtube e sites de pesquisa. Estes alunos são provenientes de uma escola pública e, segundo o Banco de Dados da escola, a renda familiar é de 3 a 6 salários mínimos. Os discursos simbólicos não apresentam claramente se pertencem a alguma tribo urbana, mas os tênis, mochilas, roupas e acessórios remetem à condição juvenil de classe média. Todos têm celulares e frequentam shoppings. Em outras palavras, os estudantes associaram a história de 
Londrina ao shopping, porque este é um lugar que frequentam, que faz sentido para seu universo socioeconômico e cultural.

Contudo, tanto o Museu Histórico de Londrina como este shopping, e também todos os outros lugares em que a história é narrada, servem de mote para discutir com os alunos em situação escolar as perspectivas diferentes em relação à história da cidade. Estes seriam "laboratórios" onde é possível mostrar com quais interesses e posições se constrói uma narrativa histórica. Mesmo o Museu, como pude observar no momento da visita dos alunos à exposição, pode ser visto de forma rápida e não reflexiva como ocorre quando se passeia no shopping, pois o modo de olhar os objetos no shopping é transposto para outros lugares. No entanto, houve intervenção do professor da turma que participou do Grupo Focal para que os objetos fossem vistos como vestígios do passado e não como "mercadorias", o que corrobora a noção de que se não há um compromisso com um trabalho didático-pedagógico com o Museu, este "transforma-se em depósito de objetos, ou vitrines de um shopping center cultural (RAMOS, 2004, p. 134). São espaços de finalidades bem diferentes, mas que em algum momento se entrecruzam, mostrando a multiperspectividade como natureza do conhecimento histórico. Como qualquer perspectiva histórica, ambas as narrativas devem ser pensadas de forma crítica.

No Grupo Focal, levantou-se a hipótese de que esta história narrada no shopping, que edifica os ingleses, seria questionável, mas não inteiramente desprezível. Ao dizer que o shopping contava a história de Londrina, um aluno foi apoiado por outros. Entretanto, iniciou-se o debate e ao final, os alunos concluíram que a história contada no shopping deveria ser problematizada. Ao final da atividade, ou seja, da visita ao Museu, solicitei que preenchessem rapidamente um folheto com o desenho de um círculo ao meio com a palavra "Londrina" e cinco hastes que ligavam a cinco círculos. Nestes cinco círculos pedi que escrevessem as palavras que associavam com a palavra central, o que se configura a técnica de brainstorming (chuva de ideias). Lembrando que esta técnica foi utilizada logo após a realização da técnica do Grupo Focal, quando havia sido problematizada tanto a história narrada no Museu como no referido shopping, os alunos associaram Londrina com palavras como: Pioneiro (45), Museu (15), Pequena Londres 
(15), Progresso (12), Desenvolvimento ou Desenvolvida (11), Modernidade (08), Calçadão 5 (07), Ingleses (07), índio (05), Lago (Igapó) ${ }^{6}$ (05), Universidade (04), Corrupção (02) e Violência, Pobreza e História (01 para cada palavra).

Nota-se que mesmo com a "memória fresca" após o debate, alguns alunos ainda citaram palavras que remetem a uma História Oficial (como Pequena Londres, que pode ser relativa ao mito fundador da colonização inglesa), embora algumas palavras como Pioneiro, não se tenha como aferir se foram colocadas de forma crítica ou não. Contudo, com as palavras Progresso, Modernidade ou Desenvolvimento, podemos entender que há a ideia da cidade como empreendedora ou progressista, uma representação que integra também a História Oficial. Palavras como Lago Igapó e Calçadão (talvez também Universidade), são associações aos lugares-símbolos da cidade e que tais estudantes têm o hábito de frequentar, enquanto Corrupção, Violência, Pobreza, dizem respeito a uma noção mais crítica. Corrupção, por exemplo, talvez se deva ao passado recente da cidade, cujos dois prefeitos foram cassados.

Creio que a metodologia do Grupo Focal fomentou a construção do conhecimento histórico, na medida em que seu objetivo "é estimular os participantes a falar e a reagir àquilo que outras pessoas no grupo dizem", ultrapassando os sentidos ou representações de natureza individual (BAUER; GASKELL, 2008, p. 75).

Se levarmos em conta a totalidade dos resultados do Estudo Exploratório, vemos que a maioria das respostas podem ser consideradas satisfatórias. A história é vista na cidade através de seus lugares-símbolos, de seus vestígios, de seus monumentos e até em um shopping (o que foi contestado no Grupo Focal). Porém, algumas ideias dos alunos ainda remetem a uma História Oficial de Londrina. Mas qual seria esta História Oficial que por vezes aparece nos discursos-sínteses dos estudantes?

\footnotetext{
${ }^{5}$ O Calçadão foi implantado em 1977 e originou-se da reurbanização das Praças Willie Davids, Marechal Floriano e Gabriel Martins, como projeto do arquiteto Jaime Lerner. Foram interditados alguns trechos para o tráfego de veículos e destinou-se esses locais ao lazer do povo londrinense e de turistas.

${ }^{6}$ Criado em 10 de dezembro de 1959, dia do Jubileu de Prata da cidade, através do represamento do Ribeirão Cambezinho. É um local de lazer, que além da represa, propicia a prática de esportes. Em 1996, o lago foi esvaziado, limpo e teve suas margens revitalizadas, ganhando ciclovia, o Teatro do Lago, jardins e chafariz.
} 


\subsection{Estudo Piloto: “Chegamos em Londrina em 1930 e não encontramos ninguém”}

Entendo aqui como sendo História Oficial, aquelas narrativas mais tradicionais recorrentes em álbuns, jornais, discursos, exposições museais, monumentos, livros didáticos $^{7}$ e também em determinada historiografia ${ }^{8}$. Na História Oficial da cidade, em síntese, prevalece a narrativa histórica construída a partir dos álbuns e publicações comemorativas, especialmente aquelas produzidas durante as décadas de 1950 e 1960, que se pautam na ideia de desenvolvimento, progresso e empreendedorismo na formação da cidade pelas mãos dos chamados "pioneiros", a despeito de outros grupos. Neste tipo de história, na época da colonização da região haveria um "vazio demográfico", ou seja, haveria apenas mata densa quando da chegada destes "pioneiros", o que resultaria em uma ocupação pacífica da região.

Não há como retomar a história da cidade neste texto, porém entendo que um recorte histórico seria importante no sentido de entender as representações dos alunos. A Companhia de Terras Norte do Paraná (CTNP), empresa de capital inglês, subsidiária da Paraná Plantations Syndicate, com sede em Londres, surgiu depois da vinda da chamada Missão Montagu ao Brasil, no ano de 1923. Essa missão contemplava interesses do governo brasileiro em atrair investimentos e novos capitais estrangeiros para o país, mas parte da historiografia também destaca que esta Missão visava analisar se a região poderia servir de garantia a um empréstimo de 25 milhões de libras solicitado por Arthur Bernardes a Rothschild. A CTNP adquiriu, entre os anos de 1925 e 1927, do governo estadual paranaense, $\mathbf{5 1 6 . 0 0 0}$ alqueires de terras, nas quais planejava investir na plantação de algodão. Com a oscilação do mercado exportador do algodão no mercado internacional, a CTNP mudou de planos para colonizar seu território e dar início ao processo de demarcação de terras e lotes, enviando uma caravana, chefiada por Lord Lovat, em agosto de 1929, com técnicos e agrimensores para a demarcação das terras.

\footnotetext{
${ }^{7} \mathrm{Nem}$ todas as narrativas dos livros didáticos usados nas escolas londrinenses na atualidade divulgam uma História Oficial. Ver: TUMA, Magda Madalena P. Viver é Descobrir - História. Geografia: Londrina, São Paulo: FTD, 2006.

${ }^{8}$ Alguns pesquisadores reproduziram o discurso oficial quanto à história da cidade, como, por exemplo, Cecília Westphalen, Ruy Wachowicz, Pedro Callil Padis, Jorge Cernev e France Luz. Outros, buscaram desconstruí-lo, e citamos entre muitos: Nelson Dacio Tomazi, Ana Maria Chiarotti de Almeida, Nadir Apparecida Cancian, José Joffily, Sonia Maria Sperandio Lopes Adum, Lúcio Tadeu Mota, Angelo Priori e José Miguel Arias Neto.
} 
demográfico", a fertilidade das terras, a ausência de saúvas, a alta produtividade da terra roxa e os preços baixos dos lotes a serem comercializados: "Londrina e suas terras, eram idealizadas por meio de expressões que a transformavam em uma espécie de terra prometida”. Seria o “El Dourado”, a “Terra da Promissão”, a “Nova Canaã” (LEME, 2013, p. 76). Assim, não apenas nas propagandas da CTNP, mas como em jornais, revistas, álbuns, se consolida uma determinada imagem, uma memória, uma história.

Estes textos, apesar da diversidade de gênero, tema e estilo, podem ser caracterizados como de "exaltação". Na perspectiva dessas obras, o norte do Paraná é a Terra da Promissão, o Eldorado, a nova Canaã, o paraíso prometido da fertilidade, da produção agrícola abundante, das oportunidades iguais de enriquecimento para todos aqueles que quisessem trabalhar e prosperar. Essas análises, não raro, trazem no bojo a ideia de uma ocupação e construção pacíficas do território, onde o capital e seus agentes foram, naturalmente, preenchendo os espaços, como se estes estivessem ansiando e esperando por aqueles. (ADUM, 1991, p. 10)

Diversos fatores influenciaram na decisão em 1944 dos ingleses de se desfazerem dos investimentos no país e, assim, a Companhia de Terras foi adquirida por um grupo paulista, e no mesmo período ocorreu a incorporação da Companhia Ferroviária São Paulo - Paraná pela Rede Viação Paraná - Santa Catarina, pertencente ao governo federal. Em 1951, a Companhia passou a se chamar Companhia Melhoramentos Norte do Paraná (CMNP). Com o final da Segunda Guerra Mundial e a normalização do comércio mundial, o preço do café subiu, o que provocou uma recuperação da economia cafeeira. A expansão dos cafezais, na região, impulsionou a economia. Londrina rapidamente se transformaria, na década de 1950, na chamada "capital mundial do café” (LEME, 2013, p. 79).

No final da década de 1950, na comemoração do Jubileu de Prata de Londrina, com homenagens e produção de um álbum da cidade, se consolida sua história através de 
É esta História Oficial que aparece em muitas narrativas dos estudantes, quando entendem o shopping como lugar de história ou quando associam a palavra Londrina com Progresso, Desenvolvimento e Modernidade. Porém, isto fica mais marcante nos resultados do Estudo Piloto.

No Estudo Piloto, utilizei a técnica de "história hipotética" influenciada pelo trabalho de Dayana de Souza (2012). Com esta atividade, pretendi fazer com que o aluno recorresse à imaginação histórica, ou seja, que levantasse hipóteses sobre como seria a vida de pessoas de determinada época e lugar. Mesmo os historiadores mais tradicionais entendem que não há como retratar a história como esta realmente aconteceu e que embora o ponto de partida seja a fonte histórica, há que interpretar esta fonte para além do que ela indica. Não há como ter acesso ao que ocorreu, mas sim em relação aquilo que poderia ter acontecido (COLLINGWOOD, 1994, p. 299). O que não significa que a “imaginação" é ficção, mas que a história, privada da imaginação, só pode fornecer informação. As hipóteses sobre o que aconteceu ocorrem em acordo com a plausibilidade histórica, o que Collingwood denomina de "interpolação". A atividade solicitada ao aluno é essa "interpolação", ou seja, a partir do que este tinha como conhecimento prévio, conteúdos substantivos e conceitos estruturais da história, obtidos pela escolarização ou pela pedagogia informal (família, amigos, mídia), indaguei o que se poderia falar sobre a história de Londrina, construindo ele mesmo uma história hipotética com o auxílio do questionário. Desta forma, o aluno utilizaria a imaginação histórica, que traduzindo, seria levantar hipóteses sobre o que aconteceu em Londrina em determinada época e com determinados sujeitos situados historicamente. A “interpolação” parte das fontes - aqui, nossos alunos partem do que sabem/lembram sobre a história de Londrina e da propaganda da Companhia de Terras Norte do Paraná que introduzi no enunciado -, e assim, os alunos constroem uma história provável segundo seus conhecimentos e/ou associações, preenchendo as lacunas através de sua imaginação/memória. Ainda com a afirmação: "História não significa saber que eventos se seguiram a quê. Significa transportar-se para o interior da cabeça das outras pessoas, observando, nessa situação 
através dos seus olhos, e pensar por si mesmo se a forma que a mesma foi abordada era o caminho certo" (COLLINGWOOD, 2002, p. 57-58 apud ARRAIS, 2009, p. 5).

Coolingwood nos reporta à empatia histórica. Peter Lee argumenta que poderíamos substituir a palavra "empatia” por “compreensão", e mais precisamente: “compreensão histórica”, que não é um sentimento, "Embora envolva o reconhecimento de que as pessoas possuem sentimentos" (LEE, 2003, p. 20). A empatia histórica remete à compreensão contextualizada do Outro que viveu no passado, mas também do Outro que vive no presente e predispõe a problematização e contextualização do Eu inserido no mundo e na interação com os Outros. Porém, mais do que se colocar no lugar do Outro, com a empatia "a nossa compreensão histórica vem da forma como sabemos como é que as pessoas viram as coisas, sabendo o que tentaram fazer, sabendo que sentiram os sentimentos apropriados àquela situação, sem nós próprios as sentirmos (LEE, 2003, p. 21).

Os estudantes, sujeitos desta pesquisa, foram chamados a preencher lacunas a partir das informações dadas, em acordo com uma determinada demarcação cronológica e espacial. Este procedimento permite uma transição do conhecimento factual, do estático, para um nível mais abstrato da história, denominada por Hilary Cooper de “imaginação dinâmica” (COOPER, 2012, p. 32-33). Os critérios de validade da história hipotética são narrativos e experimentais, e não quantitativos ou informacionais.

Inseri uma propaganda da Companhia de Terras Norte do Paraná veiculada em um jornal, mostrando uma grande figueira derrubada e dois homens ao lado. A propaganda exaltava a terra fértil e a possibilidade certa de enriquecimento na região. A partir da propaganda fiz a seguinte consideração:

“José e Dália viram uma propaganda da Companhia de Terras Norte do Paraná no jornal "O Estado de São Paulo" de abril de 1934 (abaixo) e resolveram vir para a região de Londrina com dois filhos, um de 10 anos e outro de 14 anos. Porém, não tinham dinheiro para comprar um lote de terras, e assim, vieram como trabalhadores". A partir desta consideração realizei a seguinte questão: “Imagine o que aconteceu com eles quando chegaram e descreva abaixo" e subdividi em 
10 questões: 1) O que encontraram ou viram quando chegaram em Londrina?; 2) O que fizeram logo ao chegar na cidade?; 3) Em quê eles foram trabalhar? José e Dália tinham trabalhos diferentes?; 4) O que faziam os filhos?; 5) Encontraram o que a propaganda anunciava?; 6) Porque saíram de onde estavam?; 7) Se ficavam doentes, como se tratavam? 8) Como se divertiam?; 9) Quando chegaram em Londrina o que mais desejavam José e Dália? 10) Quem eram seus vizinhos e amigos em Londrina? De quais regiões vieram?

Os alunos, nesta etapa, responderam as questões em sala de aula. Eram estudantes de duas turmas de $2^{\circ}$ ano e uma de $3^{\circ}$ ano, totalizando 64 alunos. Das suas respostas,nos pontuaram os seguintes discursos: a ideia de que Londrina era mata densa, ou seja, natureza a ser desbravada, adequada ao que a propaganda propunha (18 alunos); a ideia de que Londrina já mostrava desenvolvimento, já era uma cidade, portanto os personagens encontram o que a propaganda dizia (17 alunos); a ideia de que os personagens trabalharam muito, desbravaram a mata e encontram o progresso e de certa forma seriam "pioneiros", o que condiz com a propaganda (9 alunos). Nesta categoria, entendemos que existe uma adequação à História Oficial, aquela narrada na cidade que exalta a figura dos pioneiros. Também houve a ideia da existência de indígenas na região (apenas 2 alunos) e/ou dificuldade de ascender socialmente (10 alunos), e assim, a noção de que a propaganda seria enganosa. Um número de 8 alunos não soube ou não quis responder a maioria das questões.

É interessante perceber que, como foi solicitado que recorressem a "um exercício imaginativo", um dos alunos respondeu que a família chegando em Londrina, pediu desculpas aos indígenas por tomar suas terras. Logicamente, este tipo de diálogo jamais seria verossímil. No entanto, se considerarmos que poucos alunos se distanciaram da História Oficial, o aluno apresentou uma versão crítica da história que considera a presença indígena no território.

Com a técnica de história hipotética, os resultados quantitativos sempre são construídos através da referência cruzada e há que se ressaltar que as respostas dos alunos não podem ser encapsuladas, ou seja, o aluno poderia em um momento tender a 
recém-chegados da história hipotética: se divertiam indo aos bailes ( 53 alunos) ou à zona do meretrício, no caso dos homens (10 alunos); a mulher trabalharia não só em casa como na roça, cumprindo dupla jornada (22 alunos); as crianças, segundo as respostas, iriam todas à escola, o que é verossímil, na medida em que com o nome de Grupo Escolar de Londrina, a escola que hoje é Colégio Estadual Hugo Simas, passou a funcionar em 14 de julho de 1937 (38 alunos). Também as respostas apontaram a noção de que José e Dália saíram de locais onde antes haveria plantação de café, mas com a decadência desta cultura, houve a necessidade de vir para a região de Londrina (21 alunos). A imaginação histórica levou os alunos a considerarem que a família hipotética não enriqueceria facilmente: enfrentaria mosquitos (42 alunos), animais perigosos como cobras e onças (52 alunos), doenças (51 alunos); haveria exploração do trabalho da família pelos "pioneiros" (três alunos apontaram este fator); seria difícil desbravar a mata (53 alunos) ou morar em casa de palmito (15 alunos). Um dos alunos considerou que um dos filhos morreu de febre amarela, pois não haveria recursos na época - o que também é plausível.

Pode persistir uma História Oficial para alguns alunos quando pensam que em 1930 em Londrina encontrariam apenas mata, pioneiros, cidade. Nesta perspectiva se exalta o pioneiro e se "esquece" do indígena, bastante presente na região naquele período. Entretanto, quando se trata do cotidiano da cidade, os alunos apresentaram grande capacidade de se reportarem empaticamente para o momento inicial de colonização de Londrina.

\subsection{Estudo Principal: “A cidade conta uma história, mas a pesquisa histórica conta outra"}

Os dois primeiros estudos me levaram a compor o Estudo Principal de cunho netnográfico: "uma forma de etnografia adaptada às contingências dos mundos sociais de hoje mediados por computadores" (KOZINETS, 2014, p. 10). Geralmente, a netnografia, também chamada de etnografia digital, é utilizada para a compreensão de alguns 
fenômenos relacionados à cultura online em si, por isso o estudo é realizado em dados já existentes no mundo virtual. No caso desta pesquisa, a internet foi utilizada como mediadora de um questionário com uma temática pré-estabelecida (KOZINETS, 2014, p. 65). Na verdade, um questionário online não traz necessariamente uma inovação significativa em termos de mediação (KOZINETS, 2014, p. 69), mas sim, no que se refere ao suporte da linguagem. A opção deve-se ao fato de que na última década a chamada “segunda idade das mídias", ou melhor, a cibercultura, vem integrando o cotidiano de vários sujeitos, em especial, dos jovens. Mesmo reconhecendo que parte da população ainda estaria excluída da cibercultura, há que se destacar que este grupo de sujeitos pesquisados são bastante ativos neste ambiente (RAMOS, 2012). Além disso, os questionários são respondidos de forma anônima, o que considerei ser interessante para que os alunos dessem respostas mais espontâneas. As experiências online são bem diferentes das experiências face a face, pois o anonimato das respostas oferece uma “sensação de liberdade” (KOZINETS, 2014, p. 70). Desta forma, o Estudo Exploratório foi realizado em uma situação escolar (embora de forma externa à sala de aula), o Estudo Piloto foi realizado em sala de aula, portanto em direta situação escolar; e, o Estudo Principal, sendo realizado pela internet, aproveitou o universo cultural do aluno (este até poderia estar na escola no momento de responder como aconteceu com uma das escolas, mas não necessariamente).

Optei pela plataforma surveymonkey, que possibilita combinar uma série de tipos de questões e utilizei: pergunta de única escolha, pergunta de múltipla escolha, dissertativa, escala de avaliações e classificação. Responder o questionário era facultativo para aos alunos. O link da pesquisa foi distribuído a cinco professores de história de cinco escolas públicas diferentes, considerando apenas o Ensino Médio, que por sua vez foi divulgado na web, principalmente pela rede social do Facebook.

Neste estudo, a utilização da netnografia permitiu melhor conhecimento do sujeito da pesquisa, pois houve um bom retorno das respostas. Dos 116 estudantes que responderam o questionário, 75 são mulheres e 41 são homens, ou seja, as alunas se interessaram mais em responder os questionários, pois o número real de quantidade de alunos em sala de aula revela um equilíbrio de números entre homem/mulher. Os alunos 
do segundo ano se interessaram mais em responder o questionário, 68 alunos, contra 24 do primeiro ano e 24 do terceiro ano. Talvez se explique esta diferença pelo fato de os alunos do primeiro ano se sentirem mais inseguros quanto à linguagem digital ou mesmo em relação ao conteúdo proposto (história da cidade), e de os alunos do terceiro ano estarem mais preocupados com os estudos para o Exame Nacional do Ensino Médio (ENEM) e para o vestibular. Os alunos têm idades de 14 anos (4 alunos), 15 anos (28 alunos), 16 anos (54 alunos), 17 anos (25 alunos), 18 anos (3 alunos), e 20 anos (01 aluno). Um aluno respondeu "outra idade" e nenhum aluno tem 19 anos$^{9}$.

Em acordo com os estudos anteriores, exploratório e piloto, foi possível refletir sobre quais questões poderiam ser incluídas no questionário online, em razão de já ter antevisto que os alunos produziam determinado discurso-síntese ou mensagem nuclear. O discurso-síntese dos estudantes dos estudos anteriores apontavam para: 1) a ideia de que quando a colonizadora chegou na região de Londrina, havia apenas mata. Ou seja: haveria um "vazio demográfico", o que subentende a inexistência de indígenas, caboclos e posseiros neste momento da história da cidade; 2) a ideia de que foram os chamados "pioneiros" que desbravaram as matas e fundaram a cidade e depois produziram a cultura do café; 3) estes "pioneiros" seriam homens brancos, europeus, principalmente ingleses e são considerados como heróis da história da cidade e 4) devido à sua origem supostamente europeia, a cidade seria progressista e moderna.

Desta forma, embora a ênfase dada nesta pesquisa seja na história da cidade, os resultados do presente estudo se assemelham aos obtidos por Isabel Barca (2007), pois

\footnotetext{
${ }^{9}$ Nem todas as questões foram respondidas pelos 116 alunos. Depois destas básicas de sexo, série e idade, o aluno tinha liberdade de passar para a outra questão se preferisse não responder. Sobre as questões quanto à condição socioeconômica, realizadas pensando que esta pode influenciar na maneira como se entende a história da cidade, alguns alunos tiveram certa rejeição em responder: dos 116 alunos, 11 resolveram ignorar tais questões. Pelas respostas pode-se concluir que: a maioria não trabalha (89 alunos), diferente do Estudo Piloto em que metade dos alunos trabalhavam, pois aqueles cursavam o Ensino Médio no período noturno; a família possui carro (90 alunos) e a família possui casa própria (83 alunos). Conforme o cruzamento destes dados com as respostas em relação à escolaridade dos pais ou responsáveis e faixa de salário, podemos inferir que os alunos correspondem à Baixa Classe Média e Média Classe Média - Secretaria de Assuntos Estratégicos (SAE), ou segundo outro índice, - Associação Brasileira de Empresas de Pesquisas (ABEP), Classes B2 e Classe C1. Quando indagados sobre livro predileto, apenas 5 alunos disseram não gostar de ler, o que desconstrói a hipótese geralmente aceita de que os jovens substituíram a leitura pelo ciberespaço (embora a média diária de tempo disponibilizado para a internet por estes alunos seja de 5 horas e meia).
} 
nas narrativas dos alunos existem os seguintes marcos de consciência histórica: 1) selecionam como marcos da história da cidade a colonização realizada pela Companhia de Terras Norte do Paraná (anos 30) e o auge da cultura do café (anos 50-60); 2) têm como protagonistas da história os “pioneiros", em especial, os ingleses, sem que haja qualquer citação de um nome específico de um personagem individual; 3) a escolha destes marcos históricos e personagens históricos demonstram uma ênfase na questão econômica, e pode-se dizer que também na política, pois geralmente, estes sujeitos considerados “pioneiros" integraram e integram a política por serem de uma classe mais abastada. Apenas no Estudo Piloto, com a história hipotética, revelou-se uma ênfase na questão cultural devido ao próprio formato da metodologia e 4) tem como "sentidos da mudança" (BARCA, 2007), a ideia de progresso, o desenvolvimento sempre constante, sem rupturas. Os estudantes destacam pouco os pontos negativos da história da cidade e não há menção de uma história de temporalidade simultânea, pois se limitam a falar da cidade sem conexão com o Brasil ou com o mundo.

Pode-se inferir que a história narrada na cidade elege a memória de determinado grupo como válida, e assim, são alguns fatos, nomes e datas que perduraram e/ou se consolidaram na materialidade da cidade. A memória coletiva seria uma "escolha" permeada pelo conflito, pela disputa, sobre o que deve ser lembrado, preservado, esquecido. Existiria uma memória “clandestina” separada da memória “oficial”, e assim, primordial seria saber como algumas memórias se impõem, "como os fatos sociais se tornam coisas, como e por quem eles são solidificados e dotados de duração e estabilidade" (POLLAK, 1989, p. 04). Segundo Maryine Crivello (2013), a História Pública, a história popularizada pela mídia, pelas comemorações, pelos discursos, tende: a ser desatualizada do ponto de vista da historiografia; a ser lúdica e/ou espetacularizada (os ícones ingleses presentes na cidade são exemplos disso); a ser engajada emocionalmente (orgulho de pertencer a uma sociedade de pretenso passado glorioso); ressaltar heróis e ignorar as relações de poder e os conflitos.

O questionário online apresentou 19 questões, mas neste texto destacamos apenas duas. Optamos por explorar uma reportagem da revista Veja, A força das cidades médias, de setembro de 2010, edição 2180, destacando no enunciado: 
A paranaense Londrina é um exemplo de sucesso no interior do país. Como muitas cidades brasileiras, ela foi fundada por imigrantes, - em seu caso, trabalhadores ingleses que a batizaram em homenagem à capital de seu país - e cresceu graças a um produto: o café. Ao contrário de outros centros urbanos surgidos no século XX, contudo, Londrina nasceu planejada. O Lago Igapó, por exemplo, (...) é artificial.

A questão exigia o conhecimento de informações históricas sobre a cidade: “Existe algum erro em relação a esta reportagem? Qual?” Apesar da solicitação simples, as respostas eram dissertativas e puderam reforçar os resultados dos estudos anteriores. Na reportagem temos os seguintes “erros": 1) A cidade, como dito, não foi fundada pela imigração de ingleses, estes eram poucos, e na verdade, eram diretores da companhia colonizadora que não se estabeleceram no lugar; 2) Não foram os ingleses que batizaram a cidade, mas um político brasileiro, em homenagem à sede da companhia colonizadora; 3) Londrina nasceu planejada, mas o Lago Igapó foi planejado apenas em 1957 e inaugurado em 1959, ou seja, não nasceu com a cidade. Os "acertos" da reportagem são: 1) Se compararmos com outras cidades, Londrina foi um empreendimento de colonização de crescimento rápido; 2) A cidade surge no início do século XX; 3) Cresceu sim, com a cultura do café; 4) foi planejada pela colonizadora; 5) o Lago lgapó é artificial, pois foi formado através do represamento do Ribeirão Cambezinho.

Dos 81 alunos que responderam a esta pergunta, 46 não encontraram nenhum erro, 28 alunos disseram que o erro seria que Londrina não foi planejada, 26 alunos responderam que o Lago Igapó não é artificial e apenas dois alunos responderam que a imigração inglesa para a cidade de Londrina não procederia.

Alguns alunos fizeram algumas interpretações, embora isto não tenha sido encorajado pela questão, pois esta limitou-se às informações, aos conceitos substantivos, o que provavelmente demonstre que para tais sujeitos esta temática seria significativa. Um aluno desconfiou da natureza da "fonte": "Primeiro que ela foi feita pela Veja que não tem princípio algum, mas o erro é dizer que Londrina nasceu planejada”. Outro aluno explica de forma pertinente: “Londrina foi planejada para apenas 50 mil habitantes, o que pode ser um problema atual devido ao aumento da população (mais de 500 mil habitantes, número que provavelmente aumenta devido à vinda de estudantes de 
PLANEJADA, MAS MARINGÁ SIM”. Há alunos que consideraram um suposto erro ortográfico, talvez não entendendo o enunciado da questão: “'A paranaense Londrina' o correto seria a paranaense DE londrina". Alguns demonstraram uma posição crítica sobre Londrina como "exemplo de sucesso": "Sim, pois mesmo sendo evoluída ela precisa de muitas mudanças para ficar boa", tendo como base o presente.

Ao apontarem os "erros" da reportagem, parte dos estudantes corrobora o discurso-síntese dos estudos anteriores, com os mesmos marcos de consciência histórica. Mas mais do que isso, foi possível ver a "defesa" que realizaram sobre sua cidade. É a Outra cidade que pode ter problemas (Maringá ${ }^{10}$ ), mas Londrina não! O que foi possível perceber pela narrativa dos alunos foi a veemência quando defendiam, por exemplo, que o Lago Igapó não é artificial. O Lago não permite desconstrução por estes alunos, pois é uma imagem-símbolo, geralmente representando Londrina em cartões postais, sites sobre a história da cidade, divulgação turística. Portanto, integra as representações sobre a cidade como "paisagem" principal, carregada de significados vinculados à identidade citadina. Mesmo que um aluno tenha defendido o Lago apontando um problema: "Sim, não diria que o lago igapó é artificial, ele é bem natural se assim posso dizer, sem falar que uma das maiores partes que possui um nível de poluição elevado".

Todos nós gostamos da cidade em que moramos, nos identificamos como seus habitantes conforme a justaposição entre o que vivenciamos como objetivo e aquilo que é subjetivo. Compartilhamos valores, modos de pensar e de agir e definimos o que somos pelo que os outros não são. O que hoje é partilhado e fornece a noção identitária do londrinense, de certo, encontra respaldo na própria materialidade da cidade, mas também se baseia em uma "tradição inventada". Tradições, símbolos, fatos e

10 Maringá é um município do Estado do Paraná, sendo uma cidade média-grande planejada e de urbanização recente e a terceira maior do estado e a sétima mais populosa da região sul do Brasil. Destaca-se pela qualidade de vida oferecida a seus moradores e por ser um importante entroncamento rodoviário regional.

De acordo com o Instituto Brasileiro de Geografia e Estatística (IBGE) de 2015, Maringá possui uma população de 403.063 habitantes. Maringá dista $98 \mathrm{~km}$ de Londrina. 
personagens são constantemente reatualizados na memória da cidade através de discursos políticos, mensagens midiáticas, monumentos, educação, homenagens, arquitetura e publicações. Mas esta memória reatualizada repetidamente não é arbitrária, tanto que a pesquisa demonstrou em outra questão que a História Oficial da cidade pode ser contestada.

A questão confrontava duas reportagens de um jornal local, Jornal de Londrina. Uma intitulada Há 85 anos, Craig Smith chegou ao Marco Zero e deu início à história de Londrina, de 21 de agosto de 2014, escrita por Fábio Silveira:

De acordo com pesquisadores, a comitiva do inglês não foi a primeira que passou por Londrina, mas é tida como a oficial; seis anos depois, nasceu o Município.

O historiador, escritor e professor do Departamento de História da UEL Rogério Ivano lembra que, antes da venda das terras da região para a companhia inglesa, já existiam planos de uma ferrovia que sairia de Santos (SP), passaria pelo Norte do Paraná, seguiria até o Paraguai e chegaria ao Chile, ligando os oceanos Atlântico e Pacífico. Havia ainda um projeto de ligar Cuiabá a Paranaguá, também passando pela região onde fica Londrina. Isto demonstra que, quando os ingleses chegaram para vender terras, a área já era conhecida e existiam informações sobre ela. "Existe uma série de dados prévios que auxiliaram essa caravana."

O pesquisador e professor aposentado do Departamento de Ciências Sociais Nelson Tomazzi escreve a própria tese de doutorado sobre a construção da história de Londrina. Ele confirma que a expedição de 1929 não foi a primeira. "Foi a primeira oficialmente, ou seja, a primeira que a história oficial escolheu para colocar alguns nomes em evidência", pontua. "Na minha tese, mostro como existem vários documentos, fotografias e coisas que afirmam que não foi a primeira. Essa expedição foi a de tomada de posse.

Outra reportagem, de autoria do escritor Domingos Pellegrini, intitulada Cegueira ideológica faz professores torcerem a lógica para distorcer os fatos, de 05 de setembro de 2014, criticava a reportagem anterior.

Quando secretário da Cultura de Londrina, em reunião no Museu, pedi que pioneiros falassem da Companhia. Todos os 12 ali presentes elogiaram entusiasmados, destacando a honestidade, a produtividade e a humanidade da Companhia. Nenhuma reclamação por pessoas que a conheceram de vida e trabalho, ao contrário dos que só querem pesquisar dores. Querem achar cadáveres, injustiças e desmandos, mesmo onde não havia, como na grossa e repetida mentira de que a 
Companhia teria eliminado índios que, na verdade, nem existiam mais na região, albergados nas reservas fazia mais de século... Teria também rechaçado e massacrado posseiros, mas na verdade todos foram tirados da terra com conversação e pagamentos, civilizadamente.

Como entendi que o questionário online, embora fosse mais atrativo para o aluno responder, poderia a final causar certa fadiga para o aluno, resumi as reportagens com o seguinte enunciado extra:

REPORTAGEM 1: Em agosto de 2014, o Jornal de Londrina publicou um artigo sobre a colonização de Londrina, conforme entrevista com dois professores universitários (Rogério Ivano e Nelson Tomazzi). Estes professores diziam que quando a caravana inglesa chegou na região de Londrina em 1929, vieram para tomar posse das terras, mas já existia gente morando aqui.

REPORTAGEM 2: Depois, em setembro de 2014, em outro artigo, no mesmo jornal, um escritor (Domingos Pelegrini) contestou a opinião dos professores universitários. Diz o escritor que os professores universitários só querem achar injustiças no passado de Londrina. Segundo o escritor, ao conversar com 12 pioneiros, descobriu que não havia ninguém na região quando os ingleses chegaram, e se tinha, foram convidados a se retirar depois de muita conversa e pagamentos.

Nesta questão, tivemos 96 alunos respondentes, ou seja, 10 alunos resolveram não responder. Nota-se que, somando as respostas, não se computa o total de 96, pois as referências são cruzadas, ou seja, um aluno poderia dar mais de uma resposta. As respostas para a pergunta "Qual reportagem se aproxima mais da verdade?" foram as seguintes:

1) A reportagem 1 estaria mais próxima da verdade, pois:

a) os professores universitários, para afirmar algo, realizam muitas pesquisas (resposta de 42 alunos)

b) havia moradores na região de Londrina antes dos ingleses chegarem (resposta de 32 alunos)

c) a historiografia já descobriu que havia outros habitantes antes da chegada da colonizadora (12 alunos)

d) corresponde à história apreendida na escola (resposta de 4 alunos) 
2) A reportagem 1 e 2 estão próximas da verdade, pois:

e) As reportagens se complementam, pois havia gente em Londrina antes dos ingleses, mas foram retirados do lugar com indenizações (21 alunos)

f) Os depoimentos e a historiografia se complementam (12 alunos)

g) Os autores têm versões diferentes do mesmo fato (4 alunos)

3) A reportagem 2 está mais correta, pois:

h) Os pioneiros podem falar melhor sobre o assunto já que vivenciaram o momento histórico (18 alunos)

i) Concordam com o autor da reportagem: os professores universitários tendem a "vitimizar" pobres e indígenas ou mentir (resposta de 8 alunos)

j) A história mostra que houve indenização para os que aqui habitavam (2 alunos)

Os alunos que entenderam que a reportagem 1 seria mais próxima à realidade histórica, recorreram à legitimidade da pesquisa, da historiografia (discurso-síntese A e C), entendendo o processo de escrita da história como sendo pautado na ciência, ou então recorreram à legitimidade do que aprenderam (B e D), reconhecendo, desta forma, tanto a escola como espaço de conhecimento (D), como o conhecimento adquirido como coerente (B). Embora o discurso-síntese (B), pareça mostrar uma história como verdade inquestionável. Apesar de a questão do indígena na região não ter sido lembrada nos outros estudos ou nas outras questões do Estudo Principal, como os documentos tratavam deste assunto, os alunos entenderam que a reportagem 1, ao falar que havia habitantes antes mesmo da colonização, estava mais correta. Estas respostas se mostraram satisfatórias porque foram mais elaboradas pela perspectiva do conhecimento histórico, pois são mais explicativas. Os alunos entenderam que os argumentos apresentados na reportagem 1 eram mais fundamentados, por isso, mais próximo à verdade.

Muitos alunos procuraram apreender as duas reportagens como correspondentes a "quase-verdades" cada uma, por isso consideraram que as reportagens se complementavam, sendo que nenhuma poderia ser descartada (E). Assim como no 
discurso-síntese (B), no (E) a História se explica por si mesma, ou seja, aparece como verdade. Ou então entenderam que a historiografia não pode ser desprezada, mas também não pode ser desprezado o testemunho de quem viveu aquele momento, portanto, historiografia e testemunho se somam dando conta de uma proximidade com a verdade (F). Alguns alunos consideraram que na história há versões diferentes de um mesmo fato e não podemos desprezar esta diversidade (G). Este tipo de resposta que procura mesclar duas fontes de teorias diferentes nos leva a retomar Isabel Barca quando diz que os alunos às vezes tendem a buscar uma explicação global dos fatos ou um "conhecimento completo dos fatos" demonstrando a propensão em considerar a divergência de perspectivas como legítimas na história, mesmo que contraditórias, por isso os fatos devem ser "somados" ou "interligados" (BARCA, 2001, p. 33).

Os poucos alunos que escolheram a reportagem 2, se guiaram talvez pelo que poderia ser mais cabível se o relatado fosse sobre uma situação do momento atual, qual seja, as indenizações teriam sido pagas para quem foi retirado da região para que se iniciasse a colonização de Londrina $(J)^{11}$. Mas grande parte dos que responderam desta forma, demonstram entender que o testemunho tem mais capacidade de revelar a verdade, pois seriam os pioneiros que vivenciaram aquele momento e por isso podem contar sobre este com isenção $(H)$. Embora poucos tenham inferido que a reportagem 2 estaria mais correta em razão de os professores universitários tenderem a "vitimizar" pobres e indígenas (I), este modelo de interpretação se mostrou mais preocupante. É uma representação que vem crescendo na sociedade, que toma de forma pejorativa o saber histórico ensinado. Produtos midiáticos vêm divulgando a noção de que o professor

\footnotetext{
${ }^{11}$ Quanto a este fato, sobre as indenizações, enquanto uma historiografia considerada mais tradicional entende que "alguns poucos posseiros encontrados foram removidos, sendo reassentados em outras áreas", e que a colonizadora se comprometeria a pagar indenizações a "todos aqueles que apresentassem títulos de propriedade, o que realmente foi feito" (CERNEV, 1988, p. 118), a historiografia considerada mais crítica contradiz estas afirmações, destacando os conflitos existentes na época da colonização, pois na região já habitavam indígenas, caboclos e posseiros. Tais conflitos foram narrados por funcionários da própria colonizadora, que ainda destacaram que esta possuía uma força policial particular para retirada destes habitantes da terra. Para Tomazi, um dos professores universitários destacados na reportagem 1, o processo de colonização, foi, na verdade, um processo de (re)ocupação em que a violência foi silenciada (TOMAZI, 1999). Segundo Tomazi é que a CTNP/CMNP, como também outras companhias colonizadoras, "possuíam uma "guarda particular", bem como utilizavam-se de "jagunços", também denominados de "limpa trilhos" ou "quebra milho" para remover e sanear as terras compradas" (1997, p. 225).
} 
esta literatura midiática, atrasados, vagabundos e ignorantes, no passado e no presente (RAMOS, 2015). Não apenas os materiais midiáticos, mas os movimentos sociais, vêm apelando para a suposta "ideologia” presente na escola. Atualmente, o programa Escola Sem Partido vem cooptando variados grupos e se consolidando como proposta legislativa. Este programa entende que as escolas vêm sendo instrumentalizadas a favor da ideologia de esquerda, que veicularia uma visão unilateral, preconceituosa ou tendenciosa das questões políticas e sociais e, por isso, reivindicam neutralidade na sala de aula.

\section{Considerações finais}

Importante perceber que os conteúdos históricos relacionados à História da Cidade integram os currículos e, consequentemente, os livros didáticos nos primeiros anos do Ensino Fundamental I, mas a pesquisa foi realizada com o Ensino Médio. Desta forma, em tese, a História da Cidade ou a História Local, não é tratada neste nível de ensino. Por isso mesmo, o objetivo foi averiguar como os jovens alunos compreendiam a História da Cidade, após um período da escolarização sem que tal temática, supostamente, fosse central na aprendizagem histórica formal. As associações dos estudantes em relação à História narrada sobre a cidade de Londrina poderiam ter elementos da educação formal, mas os resultados da pesquisa demonstraram que estavam mais voltadas às noções que circulam publicamente na cidade. São noções advindas do grupo familiar, da mídia, da escola e construídas na vivência com a cidade, pois a cidade conta uma história.

No caso de Londrina, é possível ver a força das representações voltadas para o que podemos chamar de História Oficial. Uma permanência que significa uma memória (re)atualizada constantemente com a ajuda das narrativas que difundem-se na 
cidade. Uma memória que não pode ser vista de forma individualizada, mas que encontra referências comuns recorrentes, valores compartilhados e tensionais.

Aquela representação propagada pela Companhia de Terras Norte do Paraná de "Terra da Promissão", de “El Dourado", onde o progresso e o enriquecimento seriam certos, quase como predestinação, parece ter se fincado no imaginário da população. A meu ver, prevalece entre os alunos a noção de que o progresso da cidade seria uma temporalidade que se movimenta sempre para frente, como avanço, constante melhoramento, sem conflitos ou rupturas, orientado pela ação de determinados personagens, os “pioneiros". Em acordo com esta noção, o indígena não encontraria lugar na história, não existira no passado e nem no presente, seria "invisível” embora possa ser visto próximo às escolas pesquisadas, vendendo balaios e plantas, ou pedindo esmolas. Há outra ressalva: se "quem faz história" é o pioneiro, posso supor que os próprios alunos não se compreendem e também não compreendem suas famílias como protagonistas da história da cidade. Isto, mesmo percebendo que em uma questão do Estudo Principal: “Há quanto tempo sua família mora na cidade?”: 77 alunos disseram que sempre moraram na cidade, 22 responderam que há muito tempo, 6 disseram que faz pouco tempo que moram em Londrina e apenas 1 disse não morar em Londrina.

Uma narrativa histórica para além da "oficial" também pode ser identificada junto aos sujeitos desta pesquisa, especialmente quando: 1) debatem sobre a história da cidade em um grupo, revelando consensos e divergências, o que é próprio de qualquer interação social; 2) pensam no cotidiano da cidade em sua época de ocupação e utilizam a imaginação histórica em conjunto com associações obtidas em múltiplas esferas sociais e 3) compararam reportagens divergentes quanto ao fato de haver habitantes na região antes da vinda da colonizadora. A argumentação, a explicação e a compreensão histórica foram mais satisfatórias quando os alunos debateram ideias, usaram a imaginação histórica criando uma empatia histórica e quando analisaram comparativamente as fontes históricas.

Ao analisarem as fontes históricas, no caso da revista Veja, os alunos demonstraram uma necessidade de "defender" o que acreditam ser imagem-símbolo da cidade. Também, quando entenderam que a cidade tem uma "origem inglesa", mostram 
que seria a identidade e a alteridade. Neste sentido, "ser" londrinense implica em determinadas representações socais que se enraizaram sobre um passado edificado e parcialmente "inventado" e que se espraiam muito mais na História Pública do que na História especializada ou escolar.

Temos poucas respostas que mostram certa introjeção de que o saber histórico produzido pela historiografia e pela escola seriam insuficientes, incoerentes e mesmo "mentirosos". Quanto às duas reportagens que mostram perspectivas históricas diferentes, os alunos apresentaram grande habilidade em comparar, contrapor e argumentar. A maior parte dos alunos conseguiu optar pela reportagem mais próxima à verdade, aquela legitimada pela explicação histórica da historiografia ou da escola. Creio que este resultado me permite argumentar que, ao interpretar e comparar as fontes diferentes, ao mobilizar os conhecimentos condizentes com a construção do conhecimento histórico, os alunos puderam elaborar uma explicação histórica mais apurada. Puderam contrapor o que se aprende na História propagada nas esferas formais com aquela que se aprende nas esperas informais. Este é o desafio da escola: admitir que não está suspensa da sociedade e que se deve reconhecer os saberes, as noções, as representações, as ideias históricas dos alunos para que se aproveite a potencialidade destes sujeitos para a construção de uma racionalidade histórica crítica. 


\section{Referências}

ADUM, Sônia Maria Sperandio Lopes. Imagens do progresso: civilização e barbárie em Londrina - 1930/1960.1991. Dissertação (Mestrado em História) - UNESP. Assis (SP), 1991.

ALVES, Ronaldo Cardoso. História e vida: o encontro epistemológico entre didática da história e educação histórica. História \& Ensino (UEL), v. 19, n. 1, p. 49-69, jan./jun., 2013.

ARRAIS, Cristiano Alencar. Imaginação histórica e pensamento mediado na obra de R. G. Collingwood. In: SIMPÓSIO NACIONAL DE HISTÓRIA, XXV, Fortaleza - CE, 2009. Anais... . Fortaleza: ANPUH, 2009.

BARCA, Isabel. Concepções de adolescentes sobre múltiplas explicações em história. In: BARCA, Isabel (Org.). Perspectivas em educação histórica. Actas das primeiras Jornadas Internacionais de Educação Histórica. Minho: Centro de educação e Psicologia, Universidade do Minho. 2001.

BARCA, Isabel. Educação histórica: uma nova área de investigação. In: ARIAS NETO, José Miguel (Org.). Dez anos de pesquisa em ensino de história. Londrina: AtritoArt. 2005.

BARCA, Isabel. Investigação em educação histórica: fundamentos, percursos e perspectivas. In: OLIVEIRA, Margarida Maria Dias de; CAINELLI, Marlene Rosa; OLIVEIRA, Almir Félix Batista de. (Orgs.). Ensino de história: múltiplos ensinos em múltiplos espaços. Natal, RN: EDFURN, 2008.

BARCA, Isabel. Marcos de consciência histórica de jovens portugueses. Currículo sem Fronteiras, v.7, n.1, p.115-126, 2007.

BARCA, Isabel. Investigação em educação histórica em Portugal: esboço de uma análise. In: BARCA, Isabel; SCHMIDT, M. A. (Orgs.). Educação histórica: investigação em Portugal e Brasil. Braga: Centro de Investigação em Educação/Universidade do Minho. 2009.

BARROS, José D’Assunção. Cidade e história. 2 ed., Petrópolis, RJ: Vozes, 2012.

BARTHES, R. Semiótica e urbanismo. In: BARTHES, R. A aventura semiológica. São Paulo: Martins Fontes, 1985.

BAUER, Martin W.; GASKELL. Pesquisa qualitativa com texto, imagem e som: um manual prático. 7. ed., Petrópolis, RJ: Vozes, 2008.

BERGMANN, Klaus. A História na reflexão didática. Revista Brasileira de História. v.9, n.19, p. 29-42, set.89/fev.90. 
CERNEV, Jorge. Liberalismo e colonização: o caso do Norte do Paraná.1988. Dissertação ( Mestrado em Filosofia ) - Universidade Gama Filho. Rio de Janeiro, 1988

CHARTIER, Roger. A história cultural: entre práticas e representações. Trad. Maria Manuela Galhardo. Rio de Janeiro: DIFEL, 1990.

CHARTIER, Roger. Do livro à leitura. In: CHARTIER, Roger (Org.). Práticas de leituras. São Paulo: Estação Liberdade, 1996.

CHARTIER, Roger. Cultura escrita, literatura e história: conversas de Roger Chartier com Carlos Aguirre Anaya, Jesús Anaya Rosique, Daniel Goldin e Antonio Saborit. Trad. Ernani Rosa. Porto alegre: ARTMED, 2001.

COLLINGWOOD, R. G. A ideia de história. Lisboa: Editorial Presença, 1994.

COOPER, Hilary. Didáctica de la história en la educación infantil y primária. Madrid: Ediciones Morata, 2012.

CRIVELLO, Marylene. Usages publics et mises en spectacle de lihistoire dans la France contemporaine: contrastes mémoriels. Cahier d'histoire immediate. Les Usages du Passé. n. 43, p. 7-20, 2013.

EDWARDS, Verónica. Os sujeitos no universo da escola: um estudo etnográfico no ensino primário. Trad. Josely Vianna Baptista. São Paulo: Ática, 1997.

GOODSON, Ivor. História del currículum: la construccion social de las disciplinas escolares. Barcelona: Ediciones Pomares-Corredor, S. A., 1995.

GOODSON, Ivor. O currículo em mudança: estudos na construção social do currículo. Lisboa: Porto Editora, 2001.

HOBSBAWM, Eric. Introdução In: HOBSBAWM, Eric. RANGER, Terence. A invenção das tradições. Rio de Janeiro: Paz e Terra, 1984.

KOZINETS, Robert V. Netnografia: realizando pesquisa etnográfica online. Trad. Tatiani Melani Tosi e Raúl Ranauro Javales Júnior. Porto Alegre: Penso, 2014.

LEE, Peter. Nós fabricamos carros e eles tinham que andar a pé: compreensão das pessoas do passado. In: BARCA, Isabel. (Org.). Educação histórica e museus. Braga: Centro de Investigação em Educação; Instituto de Educação e Psicologia; Universidade do Minho, 2003. 
LEFEBRE Fernando; LEFEBRE, Ana Maria. Pesquisa e representação social: um enfoque qualitativo. Brasília: Liber Livro Editora, 2012.

LEME, Edson José Holtz. $O$ teatro da memória: o Museu Histórico de Londrina - 19592000. 2013, 276 f. Tese (Doutorado em História) - Universidade Estadual Paulista, Faculdade de Filosofia Júlio de Mesquita Filho, Ciências e Letras de Assis, Assis, 2013.

MARTINS, Gilberto de Andrade; THEÓPHILO, Carlos Renato. Metodologia da investigação científica para ciências sociais aplicadas. 2. ed., São Paulo: Atlas, 2009.

MIRANDA, Sonia Regina; BLANCH, Joan P. Cidade, memória e educação: conceitos para provocar sentidos no vivido. In: MIRANDA, Sonia Regina; SIMAN, Lana Mara Castro (Org.). Cidade, memória e educação. Juiz de Fora: Editora UFJF, 2013.

PESAVENTO, Sandra Jatahy. Cidades visíveis, cidades sensíveis, cidades imaginárias. Revista Brasileira de História. v. 27, n. 53, p. 11-23, 2007.

POLLAK, Michael. Memória, esquecimento, silêncio. Estudos históricos. v. 2, n. 3, p. 3-15, 1989.

RAMOS, Francisco R. L. A danação do objeto. Chapecó, SC: Argos, 2004.

RAMOS, Márcia Elisa Teté. O estudante de Ensino Médio nas comunidades virtuais "eu amo história" e "eu odeio história" e uma questão antiga: para que serve a história?

Antíteses, v. 5, n. 10, p. 665-689, 2012.

RAMOS, Márcia Elisa Teté. O que pensam os alunos do ensino médio sobre o ensino de história apresentado no "Guia politicamente incorreto da História do Brasil" de Leandro Narloch. Diálogos, Maringá v. 19, n.1, p. 345-367, 2015. Disponível em: < http://www.uem.br/dialogos/index.php?journal=ojs\&page=article\&op=view\&path\%5B\%5D =1063> Acesso em: 06 de dezembro de 2016 .

SANTHIAGO, Ricardo. Duas palavras, muitos significados: alguns comentários sobre história pública no Brasil. In: MAUAD, Ana Maria; ALMEIDA, Juniele Rabelo de; SANTHIAGO, Ricardo. (Orgs.). História pública no Brasil: sentidos e itinerários. São Paulo: Letra e Voz, 2016.

SARLO, Beatriz. Cenas da vida pós-moderna. Intelectuais, arte e videocultura na Argentina. Trad. Sérgio Alcides. 3. ed., Rio de Janeiro: Editora UFRJ, 2004.

SILVA, Bruno Sanches Mariante da. Os imigrantes de Londrina: uma análise hodonímica. In: CONGRESSO INTERNACIONAL DE HISTÓRIA, V, Maringá, 2011. Anais.... Maringá: UEM, 2011. 
SOUZA. Dayana de. Ideias históricas de alunos de um quinto ano sobre as primeiras vivências de uma hipotética família recém liberta no pós-abolição. 2012. Monografia ( Especialização em História Social) - UEL, Londrina. 2012.

TOMAZI, Nelson Dacio. Norte do Paraná: história e fantasmagorias. 1997. Tese (Doutorado em Ciências Sociais) - UFPR, Curitiba, 1997.

TOMAZI, Nelson Dacio. Construções e silêncios sobre a (re)ocupação da região Norte do Estado do Paraná. In: DIAS, Reginaldo Benedito; ROLLO GONÇALVES, José Henrique (Orgs.). Maringá e o Norte do Paraná: estudos de história regional. Maringá: EDUEM, 1999.

TUTIAUX-GUILLON, Nicole. O paradoxo francês: cultura histórica significativa e didática da história incerta. Educação e Realidade. v.36, n.1, p. 15-37., jan./abr., 2011. 